\title{
Rethinking public space through food processes: Research proposal for a "public city"
}

\begin{abstract}
Wide areas in urban peripheries are made up of the council housing, i.e., neighbourhoods provided by public authorities. Diverse in building forms and types, these areas are frequently equipped with large open spaces: their "public" dimension, in physical and social terms, which is currently in crisis. The aim of this article is to discuss two issues arising from this fact: how the sharing of food-related processes can have a strategic role in the redevelopment of the "public city", and how the "implicit planning" of these processes may provide useful insights to update planning tools and define new types of public spaces. A multiplicity of reflections leads to the conclusion that public spaces have declined, primarily, due to their inability to represent an increasingly fragmented and diverse society. In this respect, food recreates the primaeval sense of sharing, which encourages new forms of selfpromoted public spaces. An innovation of these spaces can be found in the ability to activate or enhance not only social but also economic and cohesive social relationship networks that can break down the mechanisms leading to isolation, closures and marginality often affecting peripheral council housing neighbourhoods.
\end{abstract}

Keywords: food spaces, food providing \& distribution, open spaces, urban design, "public city", creative practices.

\section{Food and the cities: An urban question}

For some time now, the relationship between food and city has been at the centre of research and investigations promoted by organizations, government agencies, non-profit associations and the like. Most importantly, it has been the core interest of different disciplines, not least architecture and urban planning. Since the mid-1990s, with the Second United Nations Conference on Human Settlements (Istanbul, Turkey, June 1996), scientists have become aware of how intense phenomena of global urbanization are closely related to an increasingly unsustainable agricultural production. Many studies have essentially shown the relationship between urban population growth and soil depletion, resource consumption and desertification phenomena. More generally, the significant role of cities has emerged in the intensification of climate change issues, food poverty, human safety and health, etc.

The argument that these researches contribute to, outline and support is clear: sustainability and urban spaces survival are strongly linked to food production and distribution cycles (Cheema et al., 1996; Mougeot, 2005, 2006; Morgan, 2009; Food and Agriculture Organisation of the United Nations, 2009, 2011; Steel, 2013; de Zeeuw \& Dreschel, 2015). The "food system"understood here as both the processes related to its production and distribution, and the practices related to food knowledge, accessibility and consumption-is therefore considered as a major urban issue intertwining with problems related to mobility, social inequalities and the environment (Secchi, 2010, 2013; Calori \& Magarini, 2015). The premise on which the different positions in a broad and disciplinarily heterogeneous debate converge is clear: if the current food production system cannot guarantee the future sustainability of urban populations, it is obvious that cities should begin to deal with agriculture, at different scales and at different levels (Cheema et al., 2001; Morgan, 2009). In recent years, the relationship between food and 
city has been dealt with across general and global issues. Ultimately, we could say that this question has polarized around three major lines of reflection and research, including different variants.

The first line focuses on food security issues. Powerfully emerged in the international debate since the 2008 global economic crisis, this strand has brought the focus back to the urban problems associated with the increasing social inequalities and poverty in cities (Food and Agriculture Organisation of the United Nations, 2004). The investigations and studies spurred by these issues are rooted in the hypothesis that integrating the food system into the urban processes can contribute in various ways to counteract poverty and food insecurity phenomena (Food and Agriculture Organisation of the United Nations, 1996). Having access to proper and healthy nutrition is not only a way to improve people's lifestyles, but can also offer job opportunities, social emancipation and the establishing or strengthening of collective collaboration and social support networks.

The second strand which the food-city relationship can be traced back to refers to environmental issues and climate change: in this case, the attention focuses on the soil as a resource and the problems linked to desertification processes, fertile land reduction, and land-grabbing phenomena (Fiamingo et al., 2016). Emphasis is generally put on the critical issues connected to the industrialization of the agricultural sector, not least those of landscape simplification and impoverishment. These affect many territories, including Italy, and carry cultural and identity questions with them, together with the more obvious environmental ones (e.g., Baccichet, 2016). Local cultural traditions, in fact, can help preserve and defend the environmental quality and ecological wealth of territories. The studies that investigate this field draw on the hypothesis that rethinking agricultural production cycles, even when they are close to the city, can be a way to safeguard and enhance the agricultural landscape, restore its peculiar traits and make our territories more resilient to climate change (de Zeeuw et al., 2011; ICLEI, 2013).

The third line, closely connected to the previous ones, reinterprets and rethinks cities from an agricultural perspective. This field has to date produced the most stimulated proposals and design themes, starting with the definition of "urban countryside" (Donadieu, 1998) and recovering those approaches in the history of architecture and urbanism which have imagined the rural dimension as an integral part of cities. Among them, let us mention Ebenezer Howard's Garden city (1898), F. L. Wright's Broadacre city (1934-35), and, more recently, Andrea Branzi's Agronica (1993-94) or Aldo Cibic's proposals presented at the 2010 Venice Biennale (Cibic, 2010). In other words, the relationship between food and city in the urban planning domain has brought renewed attention to "city design", including new landscape utopias such as the urban countryside itself, endorsed by the desires and needs of diversified and crosscultural social groups pushing for a country's return into the city (Donadieu, 2005). The most recent and well-known projects for Le Grand Pari(s) (2007), Agropolis München by Jorge Schröder and Kerstin Hartig (2009), as well as Active Nature by Soa Architects and Agence Babylone (2007), all envisage future cities as places where agricultural areas and built spaces are reassembled into new urban forms, even if they are perhaps too easily pictured in a peaceful and "natural" coexistence (Pellegrini, 2015).

It goes without saying that these thematic fields can help us rethink the relationship between food and city only if taken together. On the other hand, thus distinguished, they are a way to focus on some key issues integrating the "food system" and the "urban system". In addition, the very attention paid by some big cities' administrations (in the global North and South) to these issues has contributed to the achievement of Urban Food Planning, an opportunity to 
integrate food-related policies with other urban policies in the sector (Pothukuchi \& Kaufman, 1999; Ferrario, 2013; Calori \& Magarini, 2015; Dansero \& Nicolarea 2016). Only recently, however, the way in which food-related policies and strategies could renew the themes and tools of public space design and, more generally, of open spaces, has been questioned. From this point of view, is it possible for us to put forward another research question: can the "food system" help define new fields for urban design? Some scholars have already pointed out that, since 2005 , urban agriculture has progressively shifted from being only a policy subject to being a design subject, too (Viljoenet et al., 2015). There are many instances confirming this trend. To date, for example, the Carrot City website (Internet 1) has collected more than 100 design experiences related to urban agriculture, highlighting the wide variety of proposed solutions: from community initiatives, housing, and rooftops up to the designing of individual "components" that can enrich and diversify open space configurations and uses.

We need to consider the food system as a "device" to rethink collective spaces in ways that are innovative and different from the well-known "urban gardens". Food can be recognized as an opportunity to rediscover the value of public space in cities and to start positive processes for the reactivation and regeneration of larger urban areas.

\section{Some research issues: Food as a regeneration instrument}

From this premise, the purpose of this article is to formulate and discuss two hypotheses:

(1) The first hypothesis is that the processes linked to food production and consumption can contribute to the requalification of council housing neighbourhoods and restart a reflection on the transformation of their open and built spaces, in order to enhance their inhabitability. The food system can help reconfigure the relationships that exist between residents and property management boards, as well as social and health services and "third parties" often involved in the management and administration processes of the same districts.

(2) The second issue deals with the possibility that the relationship between council housing neighbourhoods and food-related processes can contribute to enrich the contemporary city public space debate as well. The "food system" can, in fact, have interesting spatial repercussions, and can offer a chance to rethink the forms of public space sharing, as well as its design.

\subsection{Field definition: Some premises}

In this reflection, references will be made to specific areas of urban peripheries, namely those shaped by the "public city" in the Italian context (Di Biagi, 1986; Di Biagi, 2001). This phrase refers to the urban areas created by the public operator to meet residential needs of individuals who cannot access the private home market. The building interventions that make up the "public city" emerge today in the urban continuum as morphologically and typologically connoted "parts". Together, they offer a wide and diversified repertoire of urban forms: from organic neighbourhoods (e.g., Borgo San Sergio in Trieste, Falchera in Turin) to large single compounds (e.g., Corviale in Rome, Rozzol Melara in Trieste). These forms translate different ideas of inhabitable space and its relations with the city on the ground, exemplifying different planning seasons and approaches (Di Biagi, 2001; LaboratorioCittàPubblica, 2009). In the variety of these cases, what unites these parts is generally the wide endowment of open and collective spaces, today often marked by a spatially and symbolically "promiscuous" nature: their "public" side is deeply in crisis. Here, as elsewhere, this contributes to turning these blocks-especially in big cities-into difficult contexts where social problems are accompanied 
by problems related to the very open space and building degradation. These problems have only fostered different types of stigma and prejudice towards the public city, exacerbating its separation from the city and the exclusion from the city's dynamics.

In recent years, however, studies and research conducted on some Italian cities (including Milan, Rome, Bari, Trieste, Naples, and others) have started to show how these urban parts are not only critical places but also spaces rich in resources, especially social and environmental ones (LaboratorioCittàPubblica, 2009; Infussi, 2011). These surveys have reconsidered public peripheries, seeing them as creative workshops for inserting innovative retraining paths and testing new forms of design (Infussi, 2007). Since then, many investigations have explored the possibility of promoting "research-action" lines in those districts (Cognetti, 2016; Cognetti \& Ranzini, 2017), involving not only residents, administrations and public bodies, but also cooperatives, non-profit associations, etc. On aggregate, the coordinated actions of these subjects have favoured not only renewed regeneration processes but also required completely new design tools: for example, guidelines, metaprojects and scenarios (Laboratorio Città Pubblica, 2009; Lambertini, Metta \& Olivetti, 2014; De Matteis, 2015).

It is within the limits defined by these investigations that we will try to relate food and neighbourhoods in the public city. More precisely, our focus will be on how the reorganization of food-related processes can contribute to renewing the meanings and values of the open and public spaces in neighbourhoods. First, by considering how the spaces of food and the foodrelated practices (linked to food production, preparation, consumption, education, etc.) can favour the processes of rooting, affection and care of the inhabitants in relation to the places in which they live. The public value of the food spaces is therefore recognizable, in the first place, in the capacity they have to renew shared forms of use of open spaces in the public city, contributing to their redevelopment. These are forms of sharing that take place mostly in everyday life (Di Biagi, 2013; Basso, Di Biagi, 2016), linked to rituals that, even if they are limited to a restricted sphere of intimacy (Bianchetti, 2015), can nonetheless promote paths of awareness and autonomy in weak and disadvantaged subjects.

This aspect reinforces and strengthens the hypothesis that the public value of food spaces can be recognized also and above all in their social usefulness (Caravaggi \& Imbroglini, 2016), where it is precisely through these spaces that conditions can occur for affirming fundamental rights and reducing inequalities and social distance. Finally, it is not to underestimate a more widely held public function of these spaces, that is, the value that they have in affecting the broader sustainable suburb management cycles, bringing benefits that the entire community can enjoy in terms of health, informed use of resources, strengthening of ecological and environmental networks and systems, etc. (Mininni, 2012, 2017).

\section{2 "Public city" and food safety: Spaces, rights and justice}

Observing public peripheries through the "food" lens could help us bring unexpected potentials of original and innovative projects to the surface. Neighbourhoods can be seen as the areas in which to recombine the city-food relationship while fighting for social justice and urban democracy within them and together with their residents. Food spaces and processes can work as devices to redesign and reinforce relationship networks, even economic ones, both at a large and a small scale. They can reconfigure and reactivate forsaken places. They can also modify people's routines while driving them to an awareness of the use or re-use of their living spaces, ecologically re-adapting them and increasing their resilience. 
The relation between food and council housing areas in Italy seems to be in need of thorough exploration. However, clues from a variety of spheres seem to indicate that an attention to food can be a way to activate shared processes of physical, social and urban re-qualification of these urban areas. Small yet significant experiences recorded through surveys in Italian "public city" neighbourhoods (LaboratorioCittàPubblica, 2009; Lambertini, Metta \& Olivetti, 2013; Lambertini, Metta \& Olivetti, 2014) show us how food can foster human rapprochement, soften diffidence and promote conversation and exchange. Food can become a way of undoing the established mechanisms of isolation and closures, be they internal to a neighbourhood or related to the prejudices about its spaces and inhabitants.

For quite some time, in other contexts, "food security" and "affordable housing" have been two areas where public institutions, associations and dwellers collaborated in synergy towards initiatives aiming at re-qualification of their neighbourhoods. Great Britain, the United States and Canada, with a heavier presence of eating habits problems (with serious consequences on public health and economy), identify in the food concept one of the levers for improvement of living conditions in low-cost dwellings. Some of the good practices put in place in the cities of these three countries, which have been for some time successfully promoting their food policies, show how much potential there is in strengthening the relations between food and the "public city". Even though these experiences have been conducted in culturally far apart contexts, they nonetheless suggest useful indications to initiate a regeneration process in the suburbia of our cities. In New York and London, as well as in Vancouver and Toronto, research reports, investigations, surveys and guidelines (e.g., The Food Commission, Sustain, 2005; Ostry, 2012; Population Health, 2013; Meisenheimer \& Emerson, 2015) have highlighted a close interdependence between food insecurity and council housing neighbourhoods, where people with a low income end up cutting down on food expenses in their monthly budgets. The urban issue that ties food and low-cost dwellings can be reconstructed through the relations existing between security (food and social), justice (social and health) and public health (prevention and reduction of risks in elderly people, children and poor families). Reading these documents can provide us with enough elements to reassemble the terms and suggest, in addition, possible solutions towards shared paths of social and urban re-qualification, starting from the food question.

Food insecurity (Ostry, 2012; Population Health, 2013; Meisenheimer \& Emerson, 2015) is here reduced to only two types of factors. One is individual, i.e., insufficient background knowledge and competence in order to adopt correct eating habits. The other is environmental: for example, lack of money, absence of shops selling fresh food in the area (as in the food deserts), physical impossibility of reaching a point of sale due to the lack of public transport, or, more generally, physical barriers that make it impossible for people to travel every day to buy their food. These elements, defining a socially, physically and economically precise disadvantaged condition, are then compared to a more general framework, where the risks of climate change and scarcity of resources (energy, water, etc.) urge us even more to recognize food as a field where we can intervene to increase the sustainability and quality of urban spaces, as well as improve living conditions in cities. The problem can be then described as part of a more complex urban question: "Now, more than ever, we need to grow more food, closer to where we live, that is tasty, wholesome and nutritious, than enhances rather than destroys the environment we depend on, and that satisfies people's needs for a secure and trusted food supply" (Sustain, 2008:1).

If we accept these premises, accessing wholesome and quality food should be recognized as a right that compels us to put food security and food justice on a par, and consequently, to 
consider food as an implement to obtain some forms of social justice. Community-based food initiatives can therefore help reduce exclusion and inequality (The Food Commission, 2005). What appears relevant is how these initiatives, more or less directly, act upon the many spaces in the different neighbourhoods and cities: from the big open spaces to the small ones, from the empty shells of buildings to the roofs and our everyday life vicinities, such as balconies and windowsills. Thus, the interlacing food and physical transformation practices can converge in the bigger and more integrated neighbourhood regeneration processes. Public bodies and institutions, associations, cooperatives and, more importantly, dwellers can participate in these processes involving actions influencing their daily lives at home, and find in these rituals and the other food sharing opportunities the most important success factor to their initiatives.

\subsection{Community food projects: Spaces and procedures}

Different "Community food projects" (The Food Commission, 2005; Sustain, 2008) promoted in urban neighbourhoods have been structured principally in order to configure inclusive regeneration procedures, open to the whole city. In detail, initiatives have hinged on various actions such as physical space transformation, involvement in the food-supply processes, activities for the spreading of good practices, integration of disadvantaged people and reassessment of scale economies.

Physical space transformation initiatives had a double goal. The first is the re-qualification of the abandoned public spaces within council housing neighbourhoods that were physically and socially degraded. The second is the implementation of different strategies to involve inhabitants in the transformation of these spaces, in order to spark off a process of identification together with an "appropriation" and care of the spaces themselves.

They acted on different scales and aimed to reconfigure spaces as collective meeting or public spaces. They included city farms, intended as places with a strong educational mandate translated into a variety of events, such as volunteers' welcome celebrations, school trips, etc. The traditional allotments, on the other hand, are small cultivable patches set in urban contexts, which were rented out by the council authorities to residents with the objective of improving the access to fruit and vegetables and satisfying even less common tastes determined by different ethnic origins. Garden plots and edible landscaping required less extensive areas and could be managed by nearby residents both individually and in association (e.g., Figure 1). Finally, there are the smaller and more common ornamental borders, "left-over" edges where it is possible to cultivate edible or ornamental plants. In many cases, the transformation of a neighbourhood's open spaces became an opportunity to open up its borders and find new (social) relations with the urban context into they are set. 


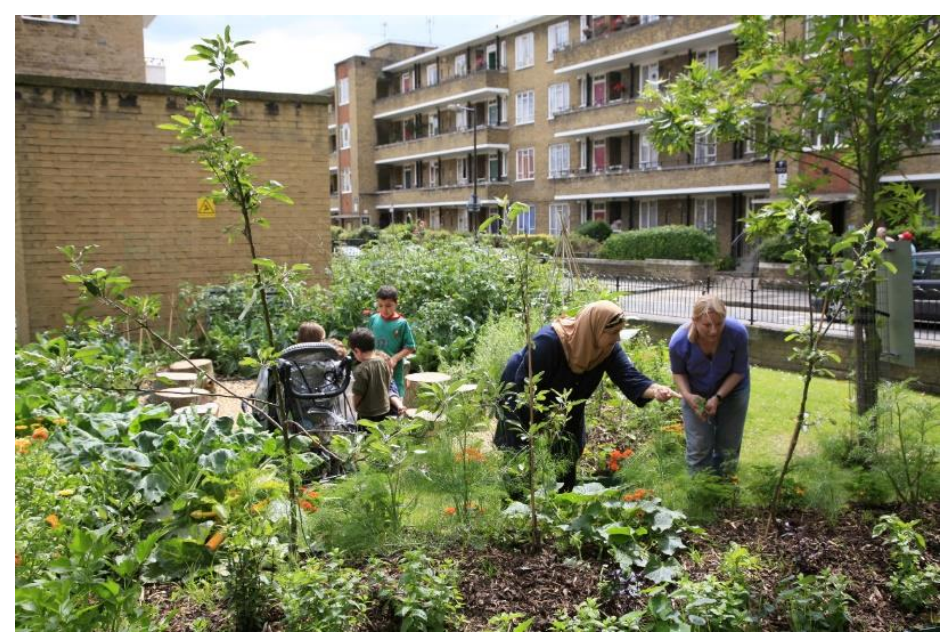

Figure 1: Brookwood Edible Garden, London (source: Internet 2).

As an example, let us take the Brixton Abundance project in London. The vague land surrounding the buildings has been used as a space to plant vegetable gardens for local citizens. The success and the wide interest raised by this initiative have opened the question of the involvement of non-residents, too, and of how to manage and distribute the produce (e.g., Figure 2).


Figure 2: Abundance project: urban agriculture demonstration plot on social housing estate maps the way forward for community food. Brixton, London (source: Internet 3).

On a smaller scale, together with the more popular roof gardens and window boxes, there were other colonization actions of domestic spaces closer to houses. The London Food Up Front initiative has helped the residents of a council housing area cultivate lettuce and other edible plants on their balconies and terraces, as well as on the front steps of the houses. Each family enrolled in the programme received a cultivation box including compost, seeds and a how-to guide, while street volunteers gave support with their expertise and advice on sowing and harvesting (Internet 4).

The Vacant-Land project, active in London since 2007, has transformed 21 sites in the British capital's peripheries. Here the re-use of bin-lining bags, normally employed for the collection of masonry waste, has allowed colonizing empty spaces in the city's suburban areas, transforming them into socialization, playground, cultivation and collective barbecue areas (Internet 5, Internet 6). In sum, these initiatives also appertain to the notion of "accessible 
health": many of the activities involving regular outdoor physical activity can, in fact, improve the health conditions of the residents.

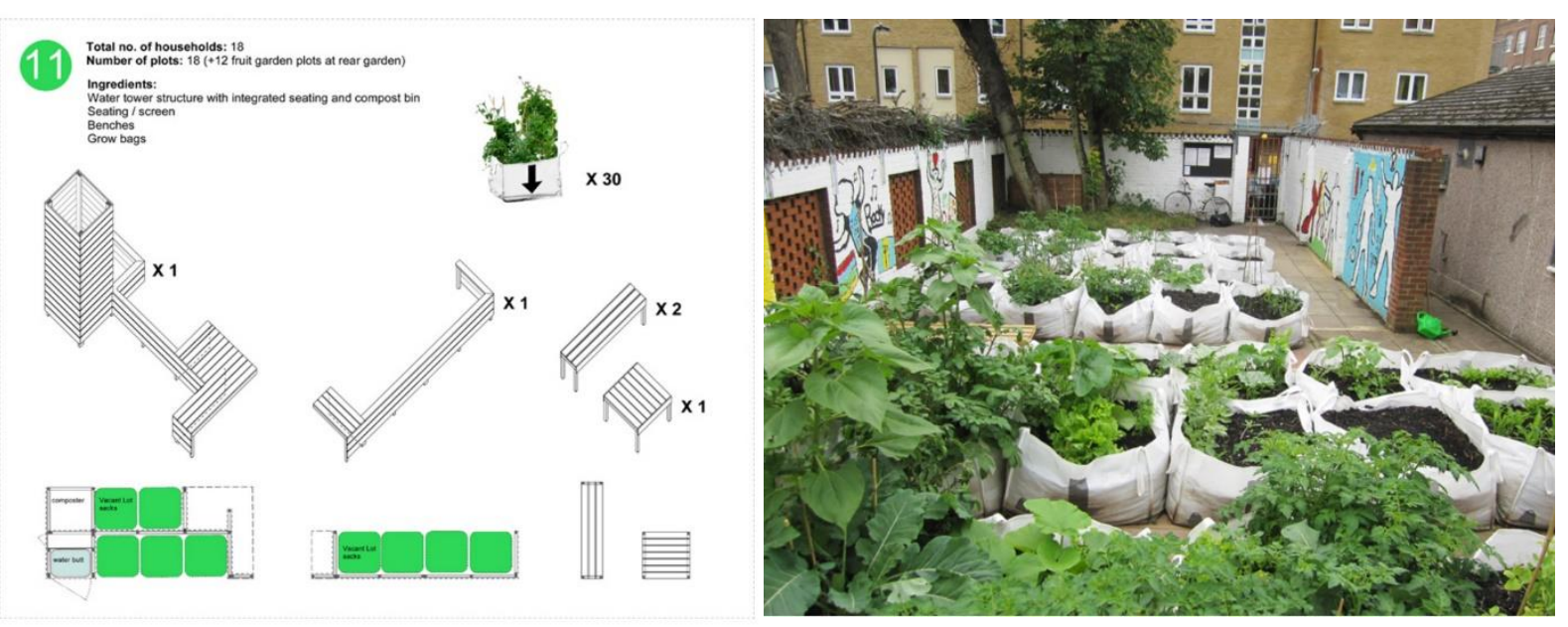

Figure 3a, 3b: Vacant Lot: Construction waste sacks used as containers for vegetable gardens and gardens in the Samuel Lewis Trust Estate district, Amhurst Park Road, Hackney, London (3a). They are modular elements used to make seats, containers for water collection and distribution, huts for tools, platform roofs, basins for ornamental plants and composting, etc. These elements redefine empty interstitial spaces in public housing neighborhoods (3b) (source: Internet 7).

The initiatives for the involvement in the food processes aimed to affect food distribution, access and selling cycles in a way that could favour the people. For example, they intended to constitute new groups, either self-organized or associated with existing circuits, to reduce the commercial brokerage between producers and consumers. This was in order to favour the access of poor and disadvantaged consumers to quality food. These projects included food cooperatives and share-a-car and food delivery schemes, all oriented to process involvement activities like cooperatives to buy wholesale fruit, vegetables and food; shared transports to reach marketplaces; food distribution, including the delivery of vegetable boxes and fresh food with lorries adapted for mobile food service (Internet 8).

Other initiatives were applied for a more equitable and efficient functioning of food production, distribution and access cycles. In this case, the initiatives aimed at disseminating the background knowledge and awareness of food consumption and distribution processes and of their environmental relevance, as well as opening up new job opportunities for unprivileged subjects through actual educational activity. In many cases, these initiatives have created opportunities to recover empty or under-used spaces in council housing buildings that could be then fully accessible also to non-residents and be turned into venues where likewise different distribution (lunch club) and education activities could take place. Such open activities can assume the form of breakfast clubs, cook-and-eat demonstrations and share-a-recipe meetings, as well as training meetings on the waste reduction of low-cost or given-for-free food. Breakfast club is a programme involving the distribution of low-cost breakfasts for school-age children to improve their health, reduce delays, prevent absenteeism and provide a basic, low-cost health care. Cook-and-eat demonstrations are generally led by nutritionists and their aim is to enhance competences and ensure healthy nutrition, that is, actions that can eventually lead to vocational training and occupation. Together with the exchange/sharing of recipes, they can help people share and partake in experiences (Meisenheimer \& Emerson, 2015). Other examples of the kind are the community cafés, started by social businesses and managed by charity organizations, where it is sometimes possible to organize food service training courses. 
Inclusion strategies have been oriented, on the other hand, to facilitate the inclusion of disadvantaged people (unemployed, immigrants, disabled people, etc.) in the community through the sharing of food production, distribution and consumption experiences. In other cases, their goal was to promote the integration of people of different ethnic origins, food handling being a possible common ground for mutual exchange and even friendship. The Bolton at Home association and the Social Housing Arts Network have started their Growing Cooking - Sharing project, focussed on social housing. Artist Sarah Butler engaged the inhabitants and new residents (especially those from immigrant backgrounds) of Breightmet, Bolton, in a "getting to know your neighbour" experience through activities like cultivation of vegetables and cooking of traditional dishes belonging to the various national cuisines (e.g., Figure 4a, 4b). An exchange of experiences and contextual knowledge has promoted social closeness and reduced the distance among cultures, even those very distant from each other (Internet 9).
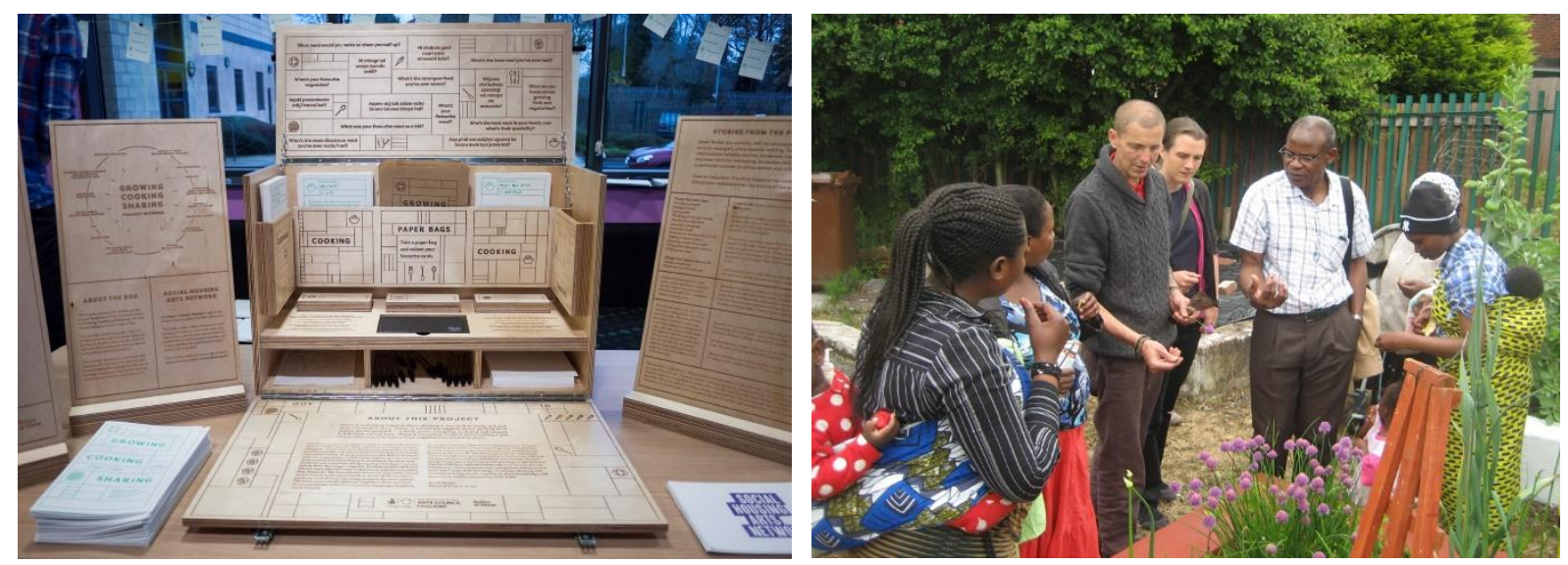

Figure 4a, 4b: In the Growing | Cooking | Sharing project, the exchange of recipes (4a), the cultivation of vegetables (4b) and the preparation of ethnic dishes become a way to encourage the inhabitants of different ethnic groups to get to know each other (source: Internet 9).

The activities for the reassessment of scale economies helped to activate collaboration networks and "economic solidarity". These networks can become a potential support for innovative business projects based on ethical micro-economies linked to their contexts, the same food production, processing and distribution cycles and other food-related products. Many of the previously analysed documents concerning the relationship between food and council housing neighbourhoods strongly underline the importance of the weaving of relations between public subjects and associations, since this improves their ability to attract funding and start new economies. Additionally, they consider the ethical background of many of these initiatives, which pressed companies to take on increased social responsibilities and offer real opportunities for the regeneration of local economies through new jobs and education (The Food Commission, 2005). Of course, these documents very often also highlight that efficient projects require an integrated approach where different actions converge in order to raise the simultaneous interest of the different actors involved (The Food Commission, 2005).

\section{Food and suburbia: What spaces?}

What can we learn from these experiences and what do they imply? Firstly, these "public city" spaces should be looked at from a new perspective. Seen through the food filter, these spaces reveal new potentials and opportunities for original and innovative projects that can in turn 
reshape the places to be shared by the people, and render them potentially eligible as new public spaces for the whole city to enjoy.

The first perspective brings food preparation and consumption, intended as practices building relations among the inhabitants, and between the residents and the environment, close to the many empty spaces characteristic of today's neighbourhoods. Originally destined for public services and facilities, they should have secured the habitability of the new city areas as well as their necessary urbanity: places where social interactions among inhabitants should have taken place. Currently, collective spaces are actually even more of a problem in many neighbourhoods, either because they were never realized or were left unfinished, or because they were run down by the passing of time, the social evolution of the residents or the shifting of their needs and expectations. Pulled down shutters and barred or walled up doors are the signs of the emptiness and neglect following changes of populations and conventions, as well as of the progressive physical and social degradation of such places. In many cases, we talk about ground floors where the proximity services that should have made these neighbourhoods vital formerly existed. Furthermore, there are interior spaces originally destined for a shared use, today the symbol of an inevitable decline. The idea of reusing them is by no means a new one: in many instances, these spaces are already being reused by house assistance services for elderly people who are lonely or sick. In Trieste, for example, the experience of the "HabitatMicroaree programme", started in 1998 through a partnership between Trieste City Council, ASL (the local health authority) and Ater (the local social housing authority), is significant. Among the many services running, a "social concierge" hosted in the neighbourhoods" communal spaces offers help and support to citizens (Internet 10).

Correspondingly, why not rethink these spaces as aggregation places where people invited may rediscover food as a trigger for education and socialization? They could become spaces where people from different classes and ethnic origins can mutually learn to know one another through the cooking and preparation of food, or where children can discover and handle it in full awareness. Why not rethink them as spaces where the elders can give new value to their traditional food culture while passing it down to the younger generations? These closed up and forsaken places can then potentially turn into generators of a new urbanism, diluting the rigid borders between the inside and the outside, the public and the private, the individual and the collective; thus expanding domesticity into the external space.

The second perspective creates a dialogue between food spaces and mediation, in-between neighbourhood spaces. They often have neither a role nor a name, are inactive and neglected, and quite often misappropriated or misused by residents (Di Biagi, 2013; Basso, 2015). However, it is in their informality (also intended as "absence of form") that we can see their potential modification, even if a transient one, able to graft ideas of possible alternative and shared uses. Here we do not mean only the "in-between spaces" made available for virtuous uses by environmental permeability (the most frequent case in point being land destined for vegetable gardens), but also the materially hostile, non-ecological spaces like hard concrete surfaces that could host practices linked to food consumption or communication. These surfaces can turn into a support for playful and creative activities hinging on food and its sharing.

The third, final perspective interprets food spaces as devices for rebuilding the relationship between neighbourhoods and city, as well as between neighbourhoods and large natural areas. Today, agricultural practices can redesign and liven up the torn edges of towns. Urban vegetable gardens, as well as other local traditional forms of cultivation, offer themselves as opportunities to redesign relations of proximity with the natural systems often lying close to town quarters. 
Food production spaces would thus earn a chance to become the devices for a "social approximation", but also for an approximation to a natural dimension, mostly dormant or denied. This could be the cue to reflect on the constitution of territory-wide, ecologicalenvironmental, even production networks: an invitation to imagine the neighbourhoods of a "public city" as "markets" where to rediscover local produce.

An additional perspective, intersecting the previous ones, suggests the possibility of considering food places as fields for conquering (or re-conquering) "spaces of rights", in both the "public city" areas and elsewhere. We are referring to a right not only to dwell in a place but a more general right to the city (and to citizenship), here intended as the possibility of sharing spaces and resources, the access to their fair use and the ability to act upon them with responsible use, care and management.

\section{By way of conclusion: A reflection on design for a new idea of public space}

Observing council housing neighbourhoods and their spaces through the "food lens" is also an opportunity to articulate another, more general reflection on the form and nature of public spaces in contemporary cities. The examples and hypotheses put forward so far agree in acknowledging a "public" character to the spaces where practices and processes connected with food (production, processing, education, consumption, sale, etc.) take place, here interpreted as being potential "accessibility devices". Thinking about the public space in these terms means to appreciate its meaning and value as a place offering opportunities to share:

- Practices (collective or individual), here intended as practical ways for the recovery, transformation and maintenance of different inhabitable places: from residential threshold spaces to peripheral spaces located between neighbourhoods and urban countryside;

- Forms of knowledge about food and food-related processes. "Food system" education can offer a chance to obtain individual or collective emancipation, which can develop into the affirmation or widening of the rule of law, starting from the right to a healthy and balanced diet, and expanding into the rights to dwell, to work, etc.;

- Resources, that is, the creation of an opportunity of managing and using landscape, environmental, cultural and food resources for various ends linked to, for example, the economy, free time, individual subsistence, etc.;

- Construction of (social and economic) innovation paths, able to positively affect new economies: for example, through the setting up of short economic chains configuring peripheral neighbourhoods and their related spaces as nodes in "zero-km" food production and sale networks, involving citizens, non-profit organizations, social cooperatives and public and private subjects.

However, how can these varieties of public space interpreted in terms of "accessibility devices" interface with innovative design forms? Our first move may be to try to outline some potential design research topics in the form of provisional conclusions.

\subsection{Three possible design research fields}

A cross-reading of reference cases, experiences and literature requires the translation of the relationship between food and public city spaces into a first, provisional definition of some design fields (Infussi, 2009). 
A first design field can be identified considering food spaces as an opportunity for constructing a complex urban welfare infrastructure (Calori \& Magarini, 2015; Dansero \& Nicolarea, 2016), where policies and projects focussed on the "food system" are mixed in a new perspective of social sustainability. As we have seen, food can become in effect a device to start or strengthen active, rather than passive, welfare networks in marginal areas often burdened by problems affecting spaces and citizens, the latter often belonging to weak social categories (elderly, unemployed, occasional workers, families on the poverty threshold, etc.). A likely solution can be a "proximity welfare", where inhabitants play an active role in the enhancement of their living and environmental conditions, and where they directly concur in the definition of mutual support networks. The welfare infrastructure here referred to can find its concrete translation in a set of different spaces able to shape systems that can be read on different scales. In the planning of these systems, the open spaces of council housing neighbourhoods can carry out an important and strategic role exactly because of their accessibility potential. Concretely, such systems can be designed as:

- open spaces networks and sustainable transport networks, linking the neighbourhoods to the city, its surroundings, centricities of interest, etc.,

- productive agricultural spaces networks ranging from urban vegetable gardens to wider urban agricultural systems,

- networks, spaces and devices for a sustainable use of resources (e.g., collection and recycling of water, recycling of waste, etc.),

- "microcentres" networks, such as markets, community cafés, etc., where people can meet and share their food-related experiences.

A second design field regards the relations between open and built spaces and considers food spaces as an opportunity to reconfigure the composition schemes of "public city" areas. Among other problems, many neighbourhoods face the buildings' indifference to the surrounding environment. The missing relationship with their contexts can be noticed in their shells, flat and lacking definitions not only of orientation but also of configuration and possible uses of the nearby open spaces. This design theme connects to a question that Kevin Lynch had already raised in his last reflection on the environmental problems posed by the rears of buildings (Lynch, 1991). Even before Lynch, the German architect Leberecht Migge (1881-1935), a landscape architect ahead of his time, considered the vegetable garden as a planning device fit for articulating the space outside the house in space sequences, comprising threshold and living spaces that extended the criteria of functionality and habitability of the house to the outside (Haney, 2010). He experimented upon this principle in his collaboration with Ernst May on the construction of the "new Frankfurt", building public housing neighbourhoods (e.g., in the settlements Praunheim and Romerstadt, Nidda Valley).

The legacy of this thought can now be revitalized thanks to the spreading of practices of appropriation, use and care of the neighbourhoods' residential areas proximity spaces. These spaces have been undergoing enhancement and redesign in the wake of numerous projects based on the active participation of residents (Cognetti \& Conti, 2012; Lambertini, Metta \& Olivetti, 2013; Metta \& Olivetti, 2016). The question of the rears of buildings opens up to notso-trivial design issues that can shake up the composition principles of these areas and even the relations between the internal, intimate and private spaces of lodgings with the open spaces, promoting the care and activation of places that otherwise risk to remain vague, penalized by their indefinite design. The American artist Fritz Haeg, drawing upon Migge's and Lynch's lessons, has shown how his edible gardens could become a powerful device to subvert the anonymous and repetitive order of the American grid (Haeg, 2008). Other projects (Paans \& Pasel, 2014), focusing instead more on the re-qualification of council housing neighbourhoods, 
suggested that the re-designing of rears could contribute to improved habitability and attractiveness of common spaces if one adequately deals with their compositional items: fences, access systems, vegetation borders forming permeable filters between different settings, etc.

The relation between built and open spaces can also be assessed from a design point of view by considering building shells and ground floors as "mediation spaces" where more or less expanded forms of sharing can take place. For instance, corridors and communal galleries can be transformed into vertical gardens where aromatic herbs can be cultivated. Empty rooms at the ground level can be converted into communal kitchens or community cafés, and so on. Collectively used minimal spaces are able to significantly improve the everyday, ordinary experience of living, amending in the process the anxiety generated by the inevitable hostility of the transition zones that lead from a private dimension to the vagueness and anonymity of external areas.

Finally, a third design theme highlights the power that small productive spaces in neighbourhoods have in giving birth to new ecological systems, even at larger scales, and in exploring contextually new ecological declinations of open spaces. Thanks also to currents such as landscape urbanism and ecological urbanism, today we are urged to look at open spaces in different ways. Concepts borrowed from botany and ecology such as corridor, margin, threshold, and gradient (Dramstad, Olson \& Forman, 1996), are currently useful descriptive categories to try to reinterpret the multiplicity of spaces in the contemporary city and to restore the wealth and the potential of those present in the public city. At the same time, these concepts offer opportunities to work on design forms fit for thinking (food) city spaces as places of new urban ecologies.

Sara Basso, University of Trieste, DIA Department of Engineering and Architecture, Trieste, Italy (sara.basso@dia.units.it)

\section{References}

Baccichet, M. (ed.) (2016) Il cibo produce e trasforma i paesaggi. Letture del paesaggio agrario del Friuli Occidentale. Udine, Olmis.

Basso, S. \& Di Biagi, P. (eds.) (2016) Gli “spazi del cibo” per nuove abitabilità delle periferie urbane. Territorio, 79 , pp. $17-78$.

Basso, S. (eds.) (2015) In comune. Percorsi di ricerca per un nuovo progetto di prossimità nella città pubblica. Territorio, 72, pp. 18-82.

Bianchetti, C. (2015) Intimité, extimité, public. Riletture dello spazio pubblico. Territorio, 72, pp. 7-17. DOI: 10.3280/TR2015-072001

Calori, A. \& Magarini, A. (eds.) (2015) Food and the cities. Politiche del cibo per città sostenibili. Milano, Edizioni Ambiente.

Caravaggi, L. \& Imbroglini, C. (2016) Paesaggi socialmente utili. Accoglienza e assistenza come dispositivi di progetto e trasformazione urbana. Macerata, Quodlibet.

Cheema, G. S., Smit, J., Ratta, A. \& Nasr J. (1996) Urban agriculture: Food, jobs and sustainable cities. New York, United Nations Development Programme.

Cheema, G. S., Smit, J., Ratta, A. \& Nasr J. (2001) Urban agriculture: Food, jobs and sustainable cities. Available at: http://www.jacsmit.com/book.html (accessed 30 Jan. 2018)

Cibic, A. (2010) Rethinking happiness: fai agli altri quello che vorresti fosse fatto a te: nuove realtà per nuovi modi di vivere. Mantova, Corraini.

Cognetti, F. \& Conti, S. (2012) Milano, coltivazione urbana e percorsi di vita in comune. Note da una ricerca in corso. Territorio, 60, pp. 33-38.

Cognetti, F. \& Ranzini, A. (2017) Mapping San Siro: strumenti di ricerca-azione nel/con il quartiere San Siro a Milano. In: Q4/i quaderni di Polisocial. Available at: https://issuu.com/52340/docs/q4_mapping_san_siro_def_high2 (accessed 30 Jan. 2018). 
Cognetti, F. (2016) Ri-attribuire valore e senso ai quartieri di edilizia residenziale pubblica e alla politica della casa nella città contemporanea. Percorsi attraverso il quartiere San Siro a Milano. ASUR, 117, pp. 5-25.

Dansero, E. \& Nicolarea, Y. (2016) Dalle pratiche alle politiche: costruire gli spazi del cibo. Territorio, 79, pp. 19-26.

De Matteis, M. (2015) Rigenerare le periferie venete. Sguardi, mappe e strategie operative per abitare lo spazio aperto negli insediamenti pubblici. Siracusa, Lettera Ventidue.

de Zeeuw, H. \& Drechsel, P. (2015) Cities and agriculture. Developing resilient urban food system. New York, Routledge.

de Zeeuw, H., Van Veenhuizen, R. \& Dubbeling, M. (2011) The role of urban agriculture in building resilient cities in developing countries. The Journal of Agricultural Science, 149(1), pp. 153-163. DOI: $10.1017 /$ S0021859610001279

Dramstad, W. E., Olson, J. D., Forman, R. T.T. (1996). Landscape ecology principles in landscape architecture and land-use planning. Washington, DC, Harvard University Graduate School of design.

Di Biagi, P. (1986) La costruzione della città pubblica. Urbanistica, 85, pp. 8-25.

Di Biagi, P. (eds.) (2001) La grande ricostruzione. Roma, Donzelli.

Di Biagi, P. (2013) La città pubblica. Un paesaggio dell'abitare quotidiano. In: Magnier, A. \& Morandi, M. (eds.) Paesaggi in mutamento. L'approccio paesaggistico alla trasformazione della città europea, pp. 129-135. Milano, Franco Angeli.

Donadieu, P. (1998) Campagnes urbaines. Actes Sud-École nationale supérieure du paysage de Versailles.

Donadieu, P. (2005) Dall'utopia alla realtà delle campagne urbane. Urbanistica, 128, pp. 15-20.

Ferrario, V. (2013) Paesaggi coltivati (multifunzionali). Lo spazio dell'agricoltura nella trasformazione della città contemporanea. In: Magnier, A. \& Morandi, M. (eds.) Paesaggi in mutamento. L'approccio paesaggistico alla trasformazione della città europea, pp. 137-152. Milano, Franco Angeli.

Fiamingo C., Van Aken M. \& Ciabarri L. (2016) I conflitti per la terra: Tra accaparramento, consumo e accesso indisciplinato. Pavia, Edizioni Altravista.

Food and Agriculture Organisation of the United Nations (1996) Implications of economic policy of food security - A training manual, Roma. Available at: http://www.fao.org/docrep/004/X3936E/X3936E00.HTM (accessed 30 Jan. 2017).

Food and Agriculture Organisation of the United Nations (2004) Globalization of food systems in developing countries: impact on food security and nutrition. Available at: http://www.fao.org/3/a-y5736e.pdf (accessed 30 Jan. 2018).

Food and Agriculture Organisation of the United Nations (2009) Food, agriculture and cities: challenges and priorities. Available at: http://www.fao.org/fileadmin/templates/FCIT/PDF/food-agriculturecities_advocacy.pdf (accessed 30 Jan. 2018).

Food and Agriculture Organisation of the United Nations (2011) Food, Agriculture and Cities Challenges of food and nutrition security, agriculture and ecosystem management in an urbanizing world. Available at: http://www.fao.org/3/a-au725e.pdf (accessed 30 Jan. 2018).

Haeg, F. (2008) Edible estates: Attack on the front lawn. New York, MetropolisMagazine.

ICLEI (2013) Resilient Urban Food Systems: Opportunities, challenges, and solutions. Outcomes of the Resilient Urban Food Systems Forum. Bonn.

Haney, D. H. (2010) When modern was green: Life and work of landscape architect Leberecht Migge. London, New York, Routledge.

Infussi, F. (2007) Fenomenologia del "progetto mite": per una pratica progettuale inclusiva delle diversità. In: Lanzani, A. \& Moroni, S. (eds.) Città e azione pubblica. Riformismo al plurale, pp. 63-74. Roma, Carocci.

Infussi, F. (2009) Campo del progetto. In LaboratorioCittàPubblica (2009), Città pubbliche. Linee guida per la riqualificazione urbana, pp. 114-145. Milano, Mondadori.

Infussi, F. (ed.) (2011) Dal recinto al territorio. Milano, esplorazioni nella città pubblica. Milano, Mondadori.

Internet 1: https://www.ryerson.ca/carrotcity/ (accessed 30 Jan. 2018).

Internet 2: http://www.fritzhaeg.com/garden/initiatives/edibleestates/london.html (accessed 22 June 2018).

Internet 3: https://www.flickr.com/photos/transitiontownbrixton/with/2338058366/ (accessed 22 June 2018).

Internet 4: http://lcrn.org.uk/food-front/ (accessed 30 Jan. 2018).

Internet 5: http://www.what-if.info/websites/ (accessed 30 Jan. 2018).

Internet 6: http://www.vacant-lot.info/ (accessed 30 Jan. 2018).

Internet 7: https://www.ryerson.ca/carrotcity/board_pages/housing/vacant_lot.html (accessed 22 June 2018).

Internet 8: https://www.sustainweb.org/foodcoopstoolkit/ (accessed 30 Jan. 2018).

Internet 9: http://www.urbanwords.org.uk/2015/12/growing-cooking-sharing/ (accessed 30 Jan. 2018)

Internet 10: http://trieste.aterfvg.it/index.php?id=43099 (accessed 30 Jan. 2018).

LaboratorioCittàPubblica (2009) Città pubbliche. Linee guida per la riqualificazione urbana. Milano, Mondadori.

Lambertini, A., Metta, A. \& Olivetti, M. L. (2013) Città pubblica/paesaggi comuni. Materiali per il progetto degli spazi aperti dei quartieri ERP. Roma, Gangemi. 
Lambertini, A., Metta, A. \& Olivetti, M. L. (eds.) (2014) Progettare paesaggi quotidiani. Roma, Gangemi.

Lynch, K. (1991) Wasting away - An exploration of waste: What it is, how it happens, why we fear it, how to do it well. New York, Random House.

Meisenheimer, M. \& Emerson, B. (2015) Integrating food access \& affordable housing. Vermont, Vermont Housing \& Conservation Board. Available at: http://www.vhcb.org/pdfs/training/Integrating-Food-Accessand-Affordable-Housing.pdf (accessed 30 Jan. 2018).

Metta, A. \& Olivetti, M. L. (2016) Col-azioni. Pratiche di convivialità per la rigenerazione degli spazi pubblici. Territorio, 79 , pp. $47-52$

Mininni, M. (2012) Approssimazioni alla città. Urbano, rurale, ecologia. Roma, Donzelli.

Mininni, M. (2017) MateraLucania2017. Laboratorio città paesaggio. Macerata, Quodlibet.

Morgan, K. (2009) Feeding the city: The challenge of urban food planning. International Planning Studies, 14(4), pp. 341-348. DOI: 10.1080/13563471003642852

Mougeot, L. J. A. (2005) Agropolis. The social, political and environmental dimensions of urban agriculture. Ottawa, Idrc Books.

Mougeot, L. J. A. (2006) Growing better cities: Urban agriculture for sustainable development. Ottawa, Idrc Books.

Ostry, A. (2012) Social housing and food security in British Columbia. Vancouver, Vancouver Coastal Health.

Paans, O. \& Pasel, R. (2014) Situational urbanism situational. Directing postwar urbanity. An adaptive methodology for urban transformation. Berlin, Jovis.

Pellegrini, M. (2015) Abitare territori intermedi. Declinare urbanità per riconoscere nuove forme di città. Doctoral thesis. Trieste, University of Trieste, Departement of Engineering and Architecture.

Pothukuchi, K. \& Kaufman, J. L. (1999) Placing the food system on the urban agenda: The role of municipal institutions in food systems planning. Agriculture and Human Values, 16, pp. 213-224. DOI: 10.1023/A:1007558805953

Secchi, B. (2010) A new urban question. Territorio, 53, pp. 8-18.

Secchi, B. (2013) La città dei ricchi e la città dei poveri. Roma-Bari, Laterza.

Steel, C. (2013) Hungry city. How food shapes our lives. London, Vintage.

Sustain \& Women's Environmental Network (2008) Growing Round the Houses: Food production on housing estates. Available at: http://www.sustainweb.org/publications/growing_round_the_houses/ (accessed $30 \mathrm{Jan}$. 2018).

The Food Commission \& Sustain (2005) Food access \& social housing. How London's housing associations can help their residents to gain better access to healthy and affordable food. Available at: http://www.sustainweb.org/publications/food_access_social_housing/(accessed 30 Jan. 2018).

Vancouver Coastal Health (2013) Food security in social housing action framework and resource guide. Available at: http://www.bchealthyliving.ca/health-starts-at-home-food-security-and-social-housing-2/ (accessed 30 Jan. 2018).

Viljoen, A., Schlesinger, J., Bohn, K. \& Drescher, A. (2015) Agriculture in urban planning and spatial design. In: de Zeeuw, H. \& Drechsel, P. (eds.) Cities and agriculture. Developing resilient urban food system, pp. 88120. New York, Routledge. 
124 